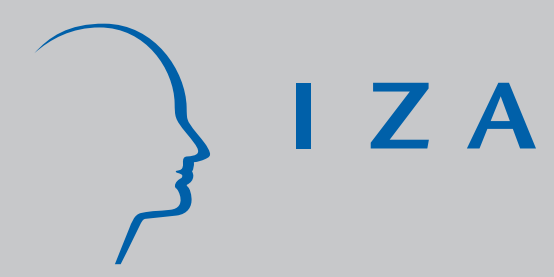

IZA DP No. 256

Eastern Enlargement and EU-Labour-Markets: Perceptions, Challenges and Opportunities

Tito Boeri

Herbert Bruecker

February 2001 


\title{
Eastern Enlargement and EU-Labour Markets: Perceptions, Challenges and Opportunities
}

\author{
forthcoming in: World Economy
}

\author{
Tito Boeri \\ Università Bocconi-IGIER, CEPR and IZA, Bonn \\ Herbert Brücker \\ German Institute for Economic Research (DIW) \\ Discussion Paper No. 256 \\ February 2001 \\ IZA \\ P.O. Box 7240 \\ D-53072 Bonn \\ Germany \\ Tel.: +49-228-3894-0 \\ Fax: +49-228-3894-210 \\ Email: iza@iza.org
}

This Discussion Paper is issued within the framework of IZA's research area Internationalization of Labor Markets and European Integration. Any opinions expressed here are those of the author(s) and not those of the institute. Research disseminated by IZA may include views on policy, but the institute itself takes no institutional policy positions.

The Institute for the Study of Labor (IZA) in Bonn is a local and virtual international research center and a place of communication between science, politics and business. IZA is an independent, nonprofit limited liability company (Gesellschaft mit beschränkter Haftung) supported by the Deutsche Post AG. The center is associated with the University of Bonn and offers a stimulating research environment through its research networks, research support, and visitors and doctoral programs. IZA engages in (i) original and internationally competitive research in all fields of labor economics, (ii) development of policy concepts, and (iii) dissemination of research results and concepts to the interested public. The current research program deals with (1) mobility and flexibility of labor markets, (2) internationalization of labor markets and European integration, (3) the welfare state and labor markets, (4) labor markets in transition, (5) the future of work, (6) project evaluation and (7) general labor economics.

IZA Discussion Papers often represent preliminary work and are circulated to encourage discussion. Citation of such a paper should account for its provisional character. 
IZA Discussion Paper No. 256

February 2001

\section{ABSTRACT \\ Eastern Enlargement and EU-Labour Markets:
Perceptions, Challenges and Opportunities}

This paper summarises the key findings of a recent study on the impact of Eastern Enlargement of the European Union (EU) on labour markets in the current Member States. The study focuses on three main channels, along which enlargement may affect labour markets in the EU, namely i) trade, ii) foreign direct investment, and iii) migration.

A main conclusion of the study is that trade and capital movements are very unlikely to lead to an equalisation of factor prices. Thus, strong economic incentives to migration are bound to be present well beyond the date of accession. We estimate the migration potential associated with Eastern enlargement drawing on a time series model of immigration to Germany, which allows to estimate the long-term equilibrium migration potential, as well as the speed of adjustment at which the potential takes place. Our findings suggest that the long-run stock of immigrants from the CEECs-10 in the EU will increase from 0.85 in 1998 to a peak of 3.9 million persons which is expected to be reached around 30 years after the liberalisation of labour movements. Net immigration inflows in the EU are bound to increase immediately reaching a maximum of about 335,000 individuals per year, and subsequently decline to a modest 100,000 to 150,000 people per annum. Around $35 \%$ of the migrants are expected to be workers.

Microeconometric exercises carried out in the context of the study indicate that such an influx of migrants will have only a moderate impact on wages and employment even in the two most affected countries, Austria and Germany. Although we are dealing with relatively small numbers, they may have an impact on wages and employment in some neighbouring regions of Austria and Germany, where immigration from the CEECs-10 is concentrated. In the final section of the paper, we argue for keeping actual migration flows from CEECs-10 under control for a transitional period. Although the chapter in the accession negotiations on the free movement of labour has been already opened, a joint position of the present EU members regarding this fundamental issue is still missing. European leaders will soon have to come to terms with this issue.

JEL Classification: F1, F2, J0

Keywords: Immigration, trade, transition, EU enlargement

Tito Boeri

IGIER

Via Salasco $3 / 5$

20136 Milano / Italy

Tel. +390258363323

Fax. +390258363302

Email: tito.boeri@uni-bocconi.it 


\section{Introduction}

The challenges and opportunities imposed by the Eastern Enlargement of the European Union are unprecedented. Differences in incomes per capita between the current members of the EU and the 10 Central and Eastern European countries (CEECs-10) candidate to accession are much larger than in previous accession episodes. Wage gaps are comparable with those registered between, on the one hand, the US and Canada, and, on the other hand, Mexico when the North-American Free Trade Agreement (NAFTA) was signed. However, NAFTA is still (Mexican President Fox is lobbying for a de-restriction of labour movements) just a trade agreement, not involving the free mobility of labour across borders and not implying strong economic integration among highly heterogeneous economies. EU accession nowadays implies a stronger degree of economic integration than even just a decade ago because of the significant progress made in the enforcement of the Single Market principles. Unlike at the time of the previous EU enlargement round, there is also today a core group of countries sharing a common currency.

Given the magnitude of income and wage differentials and the strong degree of integration involved by the accession, there are mounting concerns among the present EU members that Eastern Enlargement may have a number of undesirable effects on labour markets and income distribution. In particular, a deterioration of living standards of the unskilled workers, associated with job displacement and wage losses triggered by the inflow of low-cost labour and the de-localisation of plants from the West to the East is feared.

The textbook models of trade theory do not fully dismiss those concerns. Although the standard Heckscher-Ohlin-Samuelson (HOS) model predicts that the integration of economies which differ in their initial endowments will provide gains for all countries involved, it also suggests that the relative price of the scarce factor in each country will fall until factor prices are eventually equalised. Increasing returns to scale create additional benefits from intraindustry trade, but leave the basic propositions from the HOS-model unchanged. Moreover, if factor prices do not adjust to an increasing supply of labour, integration may involve unemployment and a net loss in welfare. Since trade and factor movements are substitutes in the standard HOS-model, it does not matter whether the barriers to trade or the obstacles to factor movements are lifted. Either trade or factor mobility, or both, contribute to the convergence of factor prices. 
Needless to say, a number of caveats apply to the predictions of the HOS-model. Firstly, neither current EU members nor the CEECs-10 resemble to the two autarkic countries which suddenly open up to bilateral trade flows of the standard trade theory. In (already) open economies such as the present EU members, only a large size of trade, capital and labour flows can have an impact on domestic labour markets, at least at the aggregate levels and the CEECs-10 are small in many respects vis-à-vis the EU. Secondly, even if the CEECs-10 were not "too small to matter", transport and transaction costs could prevent trade and factor flows from reaching the levels required to affect wages or employment in the EU. Thirdly, differences in technologies and factor intensities between the EU and the CEECs-10 may mitigate or even reverse the implications of the standard models of trade and factor mobility. Overall, factor price equalisation is just an extreme outcome within a broad range of possible consequences of the enlargement. Even if a tendency to the convergence of factor prices were to emerge as a result of the accession, it would be, in any event, a long-term process. Ten years after German unification, wage differentials in the private sector between East and West Berlin are still sizeable, after all.

The above does not mean that negative effects of accession on employment and wages should be ruled out everywhere. Specific regions, sectors and workers can suffer wage and job losses, mainly as a result of immigration. Although the overall effects of accession on EU labour markets are likely to be small, they do not appear insignificant to the workers who lobby against it. Policies coping with the accession should necessarily address these concerns as they may otherwise induce short-sighted policies, reaping the long-term benefits associated with the enlargement.

In the remaining part of this article we summarise the key findings of a recent study ${ }^{1}$ on the likely impact of Eastern Enlargement on employment and wages in the EU. As the dynamics of wage differentials plays a crucial role in this context, we will start by assessing the scope

\footnotetext{
${ }^{1}$ Tito Boeri/Herbert Brücker et al: The Impact of Eastern Enlargement on Employment and Labour Markets in the EU Member States, DIW, CEPR, FIEF, IGIER, IHS, Berlin and Milano 2000. The full report is available on the webage of the Fondazione Rodolfo Debenedetti, http: Iwww. fRDB.org. A shortened version of the report is being published by the European Commission. The report draws on contributions from Heike Berlitz, Giuseppe Bertola, Michael Burda, Fabrizio Coricelli, Juan Dolado, Per-Ander Edin, Michael Fertig, Peter Fredriksson, Helmut Hofer, Elmar Hönekopp, Peter Huber, Juan Jimeno, Janos Köllö, Michaela Kreyenfeld, Martina Lubyova, Per Lundborg, Uta Möbius, Mattia Makovec, Daniel Munich, Richard Portes, Wolfram Schrettl, Jörg Schräpler, Dieter Schumacher, Gilles St.Paul and Parvati Trübswetter.
} 
and likely speed of convergence of the CEECs-10 to the EU income levels. Then we will focus on the three main channels, along which enlargement may affect labour markets in the EU, namely i) trade, ii) foreign direct investment, and iii) migration. The enlargement

process has clearly many other facets, e.g., political, institutional and fiscal implications which will, in one way or another, affect wages and employment. This is true in particular for the Common Agricultural Policy (CAP) and the reform of structural and regional policies in the EU. An assessment of such issues goes far beyond the scope of this article.

\section{Initial Conditions and Likely Speed of Convergence}

There are marked differences between the EU and the CEECs-10 in GDP per capita at purchasing power parities: according to the most recent data available, income levels of the CEE countries range between one-third (World Bank estimates) and $40 \%$ (Eurostat) of those in the EU. Differences in GDP per capita at current exchange rates - capturing labour productivity gaps - are even larger (of the order of 85 per cent). The CEECs-10 are far from being a monolith, as the variance of income levels in the region is sizeable: per capita GNP levels at current exchange rates range between 6 per cent of the EU levels in Bulgaria and 42 per cent in Slovenia or, at purchasing power parities, between 20 and 60 per cent. Moreover, in the regions of CEECs-10 bordering the EU, wage levels can be from 20 to 60 per cent of those prevailing on the other side of the border.

Such marked gaps in real living standards and labour productivity are associated with large asymmetries in physical and human capital endowments. The book-value of physical capital stocks in the CEECs-10 is estimated at about one-tenth of the EU-average. Rather low values of the Incremental Capital Output Ratio (ICOR) in the CEECs-10 suggest that the marginal productivity of capital in the countries candidate to the accession is large relative to the EU (Table 1).

Contrary to popular wisdom, human capital endowments, measured in terms of secondary school enrolment rates and average years of schooling, are in the CEECs-10 significantly lower than in the EU. Moreover, the quality of education does not quite reach the EU standards, as suggested by international surveys of the quality of education (such as the 
International Adult Literacy Survey, and the Third International Math and Science Survey). The old regime over-invested in vocational education, offering narrowly targeted curricula and being de facto a dead-end as can be grasped from labour market outcomes of the workforce having received this type of formal education (Boeri 2000).

\section{$<$ TABLE 1>}

Although the CEECs-10 are "small" relative to the EU in terms of output and capital stocks, their labour force is not. It accounts for almost one-third of the EU labour force and is relatively "cheap": average wages reach between one-tenth (at current exchange rates) and one-fourth (at purchasing power parities) the EU levels (Table 1).

The documented asymmetries in factor endowments -- the CEECs-10 are abundant of labour while the EU is rich of physical capital - cannot, by themselves, account for the large income gaps between the two groups of countries. Total factor productivity (TFP) is indeed substantially lower in the CEECs-10 than in the EU. This suggests that a more efficient use of resources already available in the CEECs-10 has the potential to reduce the income gap vis-à-vis the EU.

Should we expect wage and income differentials to narrow down over time? If so, how long will it take before the gap is closed? Economic theory offers little guidance in this respect, while historical experience suggests that convergence may indeed occur, but only over a rather long time span. Per capita incomes within the current EU members have been slowly converging throughout the post-war period. If we apply the same pace of convergence to the CEECs-10, we can estimate the half-life of the income gap vis-à-vis the EU to be longer than 30 years. Given the differences in initial conditions across the CEECs-10, the speed of convergence will not be uniform across the board in the arena of transitional economies. Figure 1 displays our range of estimates for the time of convergence of per capita incomes of the various CEECs-10 to the income levels of the low-income EU countries (Spain, Portugal and Greece), assuming that the latter grow at a rate of 2 per cent per year. Two popular specifications for the determinants of long-term economic growth are used, the first 
attributable to Robert Barro (1991) and the second to Levine-Renelt (1992) ${ }^{2}$. The average time span for convergence is about 30 years. Even for advanced countries, like Hungary and Poland convergence to low-income EU countries will be matter of decades. It should be stressed that the projected growth rates are in line with those recently observed in these countries (the exception being the Czech Republic) following the trough of the so-called "transitional recession".

\section{$<$ FIGURE 1>}

The above assumes away any effect of enlargement on growth in the CEECs-10. However, the accession is itself likely to speed-up the convergence of per capita incomes. Estimates based on computable general equilibrium models predict that Eastern Enlargement will raise per capita GNP levels in the candidate countries by 1.5 per cent under conservative assumptions, and by around 19 per cent if we take into account the impact of EU membership on risk premiums and capital accumulation (Baldwin, Francois and Portes 1997). Moreover, sound economic policies in the CEECs-10 may speed-up economic convergence. Public administration is the only sector to have experienced a strong growth in employment levels throughout the transition period and social expenditure is largely concentrated on pensions in the CEECs-10 (Boeri, 2000). Our policy simulations suggest that a reallocation of public expenditure away from salaries of civil servants to public investment and an allocation of social spending attributing more weight to policies easing the reallocation of workers across industries rather than to pensions has the potential to increase by up to 10 per cent the speed of convergence. Improvements in institutional quality and an increase in primary and secondary education enrolment rates are also likely to foster growth in the CEECs-10. Nevertheless, any realistic policy scenario has to acknowledge that large differences in factor endowments and incomes between the current EU members and the accession candidates will persist for decades rather than simply for years.

\footnotetext{
${ }^{2}$ Barro and Levine-Renelt regressed average growth rates over long time intervals across countries against two types of variables. The first type of variables capture initial conditions (initial income per capita, and stocks of human capital) while the second type are policy variables, such as the share of Government expenditure in GDP. Projections for the CEECs-10 are obtained by multiplying the coefficients in the estimated regressions by the
} 


\section{Likely Effects of further Trade Liberalisation}

Most trade restrictions between the EU and the CEECs-10 have already been dismantled. Thus a rather strong degree of trade integration has already been attained: exports from EU countries to the CEECs-10 have grown in the last decade by a factor of 6.5 , and imports from the CEECs-10 to the EU by a factor of 4.5. The enlargement involves the integration of the CEECs-10 into the Common Agricultural Policy (CAP) of the EU, the harmonisation of product quality standards and liability rules, and the removal of the remaining trade barriers, which are confined to the service sector (and, of course, agriculture).

Standard trade theory predicts that free trade between economies with large differences in factor endowments has the potential to generate large benefits in terms of income and consumer surplus at the aggregate level, but that the gains and losses are unevenly distributed among the various factors of production. In particular, stronger trade integration of the CEECs-10 into the EU markets for goods and services could affect wages and employment by increasing imports of labour-intensive goods and exports of (physical and human) capital intensive goods, which would in turn increase the relative price of physical and human capital, and decrease wages of unskilled workers.

The composition of trade flows between the EU and the CEECs-10 is broadly in line with the predictions of these models. EU exports to the CEEC-10 are concentrated in goods with a relatively high content of physical capital and requiring highly-skilled labour, while imports from the candidate countries are based on (unskilled) labour intensive techniques. To give a few examples, import penetration of the CEECs-10 in the EU markets is stronger in sectors like clothing and footwear, while the EU experiences a large trade-surplus vis-à-vis the CEECs-10 in physical and human capital intensive industries such as communication equipment, measuring instruments, computers and motor vehicles. Although intra-industry trade is also on the rise, it is mainly of the vertical type (that is, involving goods of a different quality produced within the same industry), as indicated by the persistently large differences in unit-values between the EU and the CEECs-10.

Thus, actual trade patterns between the EU and the CEECs-10 would seem to imply a convergence in factor prices. However, there are at least two good reasons to believe that 
further trade integration will not, by itself, significantly affect relative wages and employment even in the EU countries most involved in trade with the CEECs-10:

1. Actual and projected trade volumes are just too small to affect prices in open economies. In order to affect relative wages in open economies, the CEECs-10 must become the suppliers for any additional demand of labour intensive goods. This is not likely to happen in view of the (economic) scale of the CEECs-10 and the EU. Both, EU-exports to the CEECs-10 and EU-imports from the accession candidate account for, at most, 1 per cent of the GDP of the European Union. In no country of the EU exports and imports to and from these countries exceed 4 per cent of GDP. Empirical analyses of the impact of trade on wages, employment and labour mobility based on micro data in some of the EU countries most closely integrated with the CEECs-10 (i.e. Austria, Germany and Sweden) are consistent with this view. Wage and employment effects of further trade integration are bound to be negligible.

2. The large gap in unit-values indicates that the CEECs-10 are not specialised in the same quality segments of markets as are producers in the EU. Under these circumstances, trade theory suggests that all factors of production should benefit from trade, leaving relative wages of skilled and unskilled workers unaffected.

All this does not rule out the possibility of wage and employment losses involving unskilled workers in well-defined sectors and regions. Although the magnitudes are small, trade flows are likely to be concentrated in specific EU areas because of transport costs and, due to the low mobility of workers in the EU, these regionally concentrated trade flows may locally harm the position of unskilled workers. Three quarters of trade between the EU and the CEECs-10 is indeed concentrated in the EU countries immediately bordering the accession candidate, that is, Austria, Germany, Greece, Italy and Finland (Figure 2). Moreover, within these countries, trade turnover is concentrated in the border regions. If an impact of trade on wages and employment will be felt at all in the EU, this will occur precisely in these regions.

\section{$<$ Figure 2>}

While many concerns related to the effects of trade on wages of unskilled workers appear to be ill-founded, many optimistic views as to the job generation potential of accession are likewise lacking an empirical support. It is often argued that the large surplus in EU-trade

Fischer et al (1998) and altered in the simulations discussed below). 
with the CEECs-10 is a job-generating machine. No doubt, the combined trade-surplus is sizeable (of the order of US-\$25 billions in 1998) and has steadily increased since the fall of the Berlin wall. The other side of the coin of these trade surpluses is a deficit in the capital balance as income is transferred from the EU to the CEECs-10 in order to finance their trade deficits. Increasing capital transfers to the CEECs-10 associated with the enlargement are likely to result in even larger trade surpluses. We estimate that the compounded deficit in the trade balance of the CEECs-10 may double in the course of accession.

It is difficult to establish whether trade in manufacturing goods between the EU and the CEECs-10 will significantly increase in the course of accession. Estimates based on gravity models, which explain trade flows in terms of geographical distance, population size and GDP levels at current exchange rates, suggest that actual trade flows between the EU and the CEECs-10 have already reached the potential, as they exceed 'normal' volumes registered between market economies with similar characteristics (Brenton/Mauro 1998). However, trade between the EU and the CEECs-10 is still growing at double-digit rates and there is considerable uncertainty as to the measurement of value added in transitional economies while predictions of gravity models are very sensitive to revisions of GDP series ${ }^{3}$.

An unambiguous prediction of our study is that trade in services will increase as a result of the dismantling of the remaining barriers to trade in this field. This may have a significant effect on the supply of non-tradable goods in countries and regions bordering the CEECs-10, notably in the construction and transport sectors. However, it is worth noting that present levels of service trade are low, and hence they will only rise to proportions which are unlikely to affect wages and employment at the aggregate level.

Overall, the impact of trade on employment and wages is likely to be confined to the EU countries geographically closest to the CEECs-10, and to be, in any event, concentrated in the bordering regions of these countries. Although the benefits from trade integration - in terms of increased consumers' surplus - will be significant, there will be some losers in these bordering regions, notably among the unskilled workers operating in the sectors which have so far been sheltered from the competition of low-cost labour from the CEECs-10, e.g., construction, transport and textiles.

\footnotetext{
${ }^{3}$ Schumacher (1999) shows that if one uses in gravity models GDP at purchasing power parities rather than GDP at current exchange rates, actual EU exports to the CEECs-10 in 1998 were only at about 50 per cent of 'normal' export volumes among market economies and imports at 40 per cent of their potential. There is no theoretical reason for using PPP-GDP variables in gravity models. However, this example is indicative of the sensitivity of the results of gravity models to likely errors in the measurement of GDP in the CEECs- 10 .
} 


\section{Will Plants Relocate to the East?}

Although barriers to foreign direct investment (FDI) and, more broadly, capital movements have been to a large extent dismantled, there is still poor regulation and supervision of capital markets and of the banking systems in the CEECs-10. This reduces the scope of portfolio investment of EU residents in the CEECs-10. From the standpoint of the present EU members, capital flows to the CEECs-10 are, in any event, "too small to matter": yearly capital flows currently account for barely 0.2 per cent of the EU GDP and 0.8 per cent of gross fixed investment in the EU. Even a significant increase in capital flows from such low levels, can hardly have any impact on interest rates and factor incomes in the EU. FDIs originating in the EU are, however, large for the CEECs-10 (in 1998 they accounted for 7 per cent of their GDP and more than 25 per cent of their gross fixed investment) and hence an increase in FDIs may significantly contribute to capital formation, growth, interest rates and wages in the countries candidate to accession.

Which kind of capital flows will be most affected by the enlargement and how strong will be their rise? Foreign capital flows to CEECs-10 mainly take the form of foreign direct investments. Portfolio capital inflows are well below those observed in other countries at comparable income levels. This suggests that equity and security markets of the CEECs-10 are still at their infant stage. We expect the inflow of portfolio capital to significantly pick-up as the harmonisation of the regulation of financial markets gains momentum. We also estimate FDIs to the CEECs-10 to double in the wake of accession. Experience from past enlargement episodes suggests that accession to the EU can considerably increase capital inflows: this happened especially in Spain and Portugal in the aftermath of the Southern enlargement of the EU. Furthermore, our projections for the trade potentials imply that capital flows to the CEECs-10 fall short of their potential as trade and current account deficits are usually matched by capital inflows. Such an increase in capital movements from the EU to the CEECs-10 may contribute significantly to growth in the CEECs-10, hence to income convergence.

There are widespread concerns in the EU that labour intensive productions will relocate from the EU to the CEECs-10 as a result of the enlargement. However, a detailed analysis of the structure of FDIs does not provide support to these views. Nearly half of the FDIs originating from the EU is directed at non-tradable sectors in the CEECs-10 (mainly public utilities and communication, as well as financial services). The branch structure of investment, as well as enterprise surveys, indicate that market access is the primary reason for the investment. Only 
about one-fifth of foreign investment is allocated to industries where low labour costs play a significant role and the share of unskilled labour is relatively high $^{4}$.

Overall, only a minor fraction of FDI is driven by low-wage costs in the CEECs-10 and hence may displace production and employment in the EU. FDIs are mainly induced by market access considerations: this means that they are either neutral for employment and wages in the EU or are complementary to trade, thereby exerting a positive effect on employment and wages in the enterprises and branches involved. The small fraction of FDIs induced by low labour costs is associated with a specialisation of production in human capital intensive processes in the EU and labour intensive activities in the accession candidates. This structure of FDIs may actually hurt wages and employment of unskilled workers in specific enterprises and branches, such as clothing, footwear, electrical machinery, rubber and plastic products. However, in these branches large trade surpluses vis-à-vis the CEECs-10 are observed, which suggests that the undesirable effects of FDIs on wages and employment of unskilled workers may be offset by increasing exports to the CEECs-10.

\section{Migration Scenarios}

Ten years after the start of economic transition in Eastern Europe, immigration from the CEECs-10 is still heavily restricted by the EU Members. Neither do the Europe Agreements (EAs) impair the authority of individual EU Members to regulate the immigration of labour and persons from the CEECs-10. The removal of the barriers to free labour mobility is therefore the single dimension of economic integration, which is likely to be most affected by the Eastern enlargement of the EU.

The evidence presented above does not suggest that trade and capital movements can lead to an equalisation of factor prices. Insofar as large wage and income gaps between the CEECs10 and the EU are likely to persist for decades, strong economic incentives to migration are bound to be present well beyond the date of accession. This holds true particularly for the richest regions of the EU which are bordering the CEECs-10, such as the Bavarian border with the Czech Republic and the Austrian borders with Slovakia, Hungary and the Czech

\footnotetext{
${ }^{4}$ In particular, in clothing and footwear, electrical machinery, rubber and plastic products, parent companies would seem to focus on significantly more capital intensive activities than their foreign affiliates.
} 
Republic. However, international migration is hindered by high transaction costs and by the limited absorption capacity of labour markets in the countries of destination.

Present stocks of employees and residents from CEECs-10 in the EU clearly reflect the restrictions to labour mobility and are, in view of the large gap in per capita incomes, rather negligible. The stock of foreign residents immigrated from the CEECs-10 to the EU is estimated at some 850,000 individuals, while the stock of foreign employees amounts to about 300,000 workers. The latter figure includes the full-time equivalent of temporary and seasonal workers. Such figures account for barely 0.2 per cent of the EU population and 0.3 per cent of the EU workforce, respectively. Around 80 per cent of the migrants from the CEECs-10 reside in Austria and Germany (figure 3). However, the official statistics do not cover illegal migration as well as workers which are employed by foreign companies supplying services in the present EU countries.

\section{$<$ Figure 3>}

Our estimates of the migration potential associated with the Eastern enlargement draw from a time series model of immigration to Germany in the 1967-98 period, which explicitly takes into account the formation of expectations. This model allows to estimate the long-term equilibrium level of CEECs-10 individuals and workers residing in the EU, as well as the speed at which the adjustment to the potential takes place. The most important factors affecting the estimates of the migration potential are the differences in per capita incomes, and the employment rates both in the destination countries and in the countries of origin. Institutional restrictions to migration, variables capturing the presence in the host country of ethnic minorities originating from the CEECs-10 and the possibility to use a common language as well as indicators for the standard of living, were also found to significantly affect migration. Interestingly enough, our estimates suggest that the propensity to migrate decreases with the number of those who have already emigrated from each accession candidate. Thus, network effects, e.g., associated with the presence in the EU of a core group of migrants originating from the same country, would seem to influence the distribution of migrants between the different EU countries, but not to encourage an expansion of migration flows. 
The above econometric results can be used to simulate potential migration from the CEECs10 into the EU under various scenarios of income convergence and unemployment. Needless to say, the simulations should only be seen as broad indications as to the likely magnitudes of future migration flows originating from the CEECs-10 and are conditional on the assumptions being made as to the pace of income convergence to the EU levels and on labour market developments in the East and the West.

Our baseline simulations assume that per capita incomes between the EU and the CEECs-10 will converge at a rate of $2 \%$ per annum - which is consistent with the speed of income convergence in Post-war Europe -- and that the unemployment rates in the EU and the CEECs-10 remain constant. They suggest that the foreign population originating from the CEECs-10 and residing in the EU may rise from about 0.85 to 3.9 million under the enlargement scenario. This corresponds to roughly $4 \%$ of the CEECs-10 population and one per cent of the population of the EU-15 countries. The peak in the size of the population of migrants is expected to be reached 30 years after the liberalisation of labour movements. Net migration inflows in the EU are bound to increase immediately reaching a maximum of about 335,000 individuals per year, and subsequently decline to a more modest 100,000 to 150,000 people per annum. Different assumptions as to the speed of convergence as well as the unemployment rates prevailing in the countries of destination and origin, yield long-run stocks of foreign residents from the CEECs-10 in the EU-15 ranging from 2.9 to 4.5 million (figure 4).

\section{$<$ Figure 4>}

Thus, according to our simulations, migration flows stimulated by the accession will neither be negligible -- as was the case at the time of the accession of the Southern EU Members -nor as large as often feared in the EU. The stock of foreign residents from the Southern EU Members had already reached its equilibrium level when the free movement was introduced, according to our estimates. This will hardly be the case when the CEECs-10 enters the EU. Moreover many speculations depicting Western Europe as being swamped by large cohorts of migrants originating from the CEECs-10 ignore the fact that migration is hindered by high transaction costs and do not factor in the limited absorption capacity of labour markets in the 
destination countries. Even in Germany during the 1960s, under full-employment and publicly-sponsored efforts to attract guest-workers from abroad, average net immigration from all countries never exceeded 220,000 persons per year.

Migration flows will not be evenly distributed across the EU. Germany and Austria currently attract about $80 \%$ of the migrants originating from the CEECs-10. If this geographical concentration of migration flows will not change, Germany and Austria should be expected to receive 220,000 and 40,000 people per year, respectively, after free labour mobility is introduced. As in the case of trade flows, migration flows are also concentrated in the Austrian and German regions bordering the CEECs-10, with the notable exception of the former GDR. At the borders of Eastern Germany with Poland and the Czech Republic, migration shares are at one-third of the German average, a factor which can be attributed to to the lower income levels and higher unemployment rates registered in the Eastern Länder.

Gains and losses from migration will not be uniformly distributed across the various factors of production in the EU: while complements to migrant labour will gain, substitutes may lose out. Once more, it is mainly unskilled labour that may experience wage and employment losses as a result of the enlargement. Such undesirable distributional effects are likely to be concentrated on blue-collar workers in manufacturing industries and on unskilled labour in services. As to the size of such effects, it should not be over-estimated: the impact of migration on the labour market performance of natives is much smaller than widely believed. The reason is that migrants tend to move into the most prosperous branches and regions and that output and investment are responsive to the increase in labour supply. Microeconometric exercises carried out in the context of our study suggest that an increase in the migrant share, in a given branch, by about one percentage point decreases average wages of natives by only 0.25 per cent in Austria and 0.6 per cent in the Germany. At the same time, the individual risk of dismissal increases by 0.8 percentage points in the Austrian and by 0.2 percentage points in the German sample. The impact of migration on white collar workers is found in these regressions to be slightly positive or neutral. Since the increase in the share of foreigners from the CEECs-10 is expected to last for a relatively long time period, the impact of migration on wages and employment is likely to be rather moderate even in Austria and Germany.

It should finally be stressed that migration from the CEECs-10 is likely to be more dispersed across skill groups than in previous immigration episodes. Formal educational attainments of 
migrants from the CEECs-10 are surprisingly high. Nevertheless, the branch structure of employment shows that nationals from CEECs-10 are employed in the same branches as other foreigners and most probably, at the same qualification levels. Furthermore, evidence on the labour market performance of ethnic Germans who have immigrated from CEECs-10 suggests that the returns on human capital are low even when migrants possess good language skills. Although immigrants from the CEECs-10 compete at present for jobs in manufacturing and construction sectors with native blue-collar workers and unskilled workers, they may become over time more able to adapt to the skill profile of labour demand in the EU, and increasingly compete for positions with highly-skilled workers.

\section{Summary and Conclusions with an Eye to Nice}

Trade and FDI flows associated with the Eastern enlargement of the EU are unlikely to significantly affect wages and employment in the current members of the EU. Some wage and job displacement effects of the accession may only be felt at a sub-national scale, involving unskilled workers, employed in specific industries (mainly in services, construction and transport) and resident in the relatively rich regions of the Southern EU border with the CEECs-10. In these respects, trade and FDIs, CEECs are just "too small to matter" for the current EU members. Migration associated with the liberalisation of labour movements from the CEECs-10 will certainly be more sizeable, as income gaps between the EU and the candidate countries are large, bound to persist for decades and the CEECs workforce is about $1 / 3$ that of the EU. However, history tells us that it takes a long time before migration stocks adjust to income differentials, which are themselves bound to decline over time. Even under prudent assumptions about the pace of income convergence, we expect an annual increase in the number of foreign residents from the CEECs-10 of around 220,000 persons for Germany and of 40,000 persons for Austria after lifting the barriers to labour migration. Such flows will decline over time: net flows will be halved within a decade. The above estimates assume that there are no migration restrictions at all, that is, free movement of labour from the CEECs- 10 . About one-third of migrants are expected to be employees.

Although we are dealing with relatively small numbers, they may not look that small to populations of neighbouring regions who fear a concentration of migrants where they live, and consequent risks of wage losses and job displacement for the unskilled. Almost $80 \%$ of the migrants from the CEE countries in the EU reside in Austria and Germany, and -- with the 
notable exception of Eastern Germany -- they are concentrated in the Eastern regions. Educational attainments of Eastern migrants are often relatively high, but newcomers typically compete with residents for less-skilled jobs. While in tradable sectors output adjusts to an increasing supply of labour, competition of migrants from the East may bite in nontradable sectors such as construction, hotels, restaurants or household services. Thus, Austria and Germany will be the main winners from a free movement of labour, but we cannot totally dismiss all concerns about undesirable effects on local labour markets in these two countries.

Sound enlargement policies should not neglect these concerns as well as the uncertainty inevitably associated with any estimate of the migration potential. It may therefore be advisable to keep actual migration flows under control for a transitional period. Although the chapter in the accession negotiations on the free movement of labour has been already opened, a joint position of the present EU members regarding this fundamental issue is still missing. European leaders meeting in Nice in December will have to come to terms with this issue. Some EU governments and, according to the last wave of the Eurobarometer survey, a majority of Austrians and Germans (the two populations likely to be most affected by migration flows) are against the enlargement to take place in the absence of migration restrictions, albeit temporary, vis-à-vis new entrants. Under these conditions, a delay of decisions on migration policies undermines the credibility of the commitment of the EU vis-àvis the enlargement.

Postponing decisions and maintaining a high degree of uncertainty as to the timing and conditions of the Eastern Enlargement process will backfire. A lack of credibility of the accession of CEECs-10 reduces incentives for private investors to make irreversible commitments such as those involved by business start-ups in the East or FDIs. The capacity of candidate countries to implement badly needed institutional reforms also depends on a credible agenda for accession. The prospect of entry induces citizens in the CEECs-10 to comply with the law -- which is currently better enforced in the EU -- thus easing the reforms of the state machinery and the fight against corruption. Credibility of accession can also reduce migration pressures, as decisions to migrate depend heavily on expectations regarding future income levels. In a nutshell, a lack of credibility of accession means slower convergence of per capita incomes of the CEECs-10 to EU levels and stronger incentives to migrate. 
The commitment to Eastern enlargement would become more credible if the current EU members open gradually, but immediately, their labour markets to migrants from the accession candidates. Macroeconomic conditions are favourable: Continental Europe is at the outset of an upswing in the business cycle. This eases the absorption of migration flows and minimises the risk of undesirable effects of migration on jobs and wages of unskilled workers resident in regions neighbouring the CEECs-10. In the case of the Southern enlargement of the EU, transitional periods were agreed upon which simply postponed labour migration. Those transitional periods do neither reduce the uncertainty on potential migration nor mitigate migration pressures. In contrast, immigration quotas could provide information on future migration pressures, thereby reducing the uncertainty associated with projections of migration flows, and allow to smooth pressures on host labour markets at the same time. If applications do not fill up the quotas, they can be lifted before time.

The rationale for having some temporary restrictions to migration is to prevent social tensions which may result in pressures for stronger and long-lasting migration restrictions. The credibility of the commitment of the EU to the enlargement would be stronger if such quotas are adopted immediately. It would also be enhanced if labour market and social policy institutions in the EU are reformed in such a way as to promote, rather than oppose, internal labour mobility in the EU. This would also avoid the concentration of the undesirable effects of migration on specific regions, which is the only way, after all, in which the enlargement can generate some losers in the EU. 


\section{References}

Baldwin, Richard E., Joseph F. Francois and Richard Portes, The costs and benefits of Eastern enlargement: the impact on EU and central Europe, Economic Policy, No. 24, pp. 127-176.

Barro, R. (1991) Economic growth in a cross-section of countries, Quarterly Journal of Economics, 106, 2 (May), 407-43.

Boeri, Tito (2000) Structural Change, Welfare Systems, and Labour Reallocation: Lessons from the Transition of Formerly Planned Economies, Oxford University Press, Oxford.

Brenton, Paul and Francesca Di Mauro, Is there Any Potential in Trade in Sensitive Industrial Goods Between the CEECs and the EU?, The World Economy, Vol. 21, No. 3, pp. 285-304.

Fischer, S., R. Sahay, and C.Vegh (1998) How far is Eastern Europe from Brussels, IMF Working Paper, WP/98/53.

Levine, R. and Renelt, D. (1992) A sensitivity analysis of cross-country growth regressions, American Economic Review, 82, 4 (September), 942-63.

Schumacher, Dieter, Trade Of EU Countries With Central and Eastern European Association Countries: Potential Volume and Future Patterns Of Comparative Advantage, Background Report to 'The Impact of Eastern Enlargement on Employment and Labour Markets in the EU Member States', DIW, Berlin 1999. 


\begin{tabular}{|c|c|c|c|c|c|c|c|}
\hline & \multicolumn{2}{|c|}{ GNP per capita ${ }^{1)}$} & \multicolumn{2}{|c|}{$\begin{array}{l}\text { PPP-GNP per } \\
\text { capita }^{2)}\end{array}$} & \multicolumn{2}{|c|}{$\begin{array}{c}\text { gross wages and } \\
\text { salaries }\end{array}$} & \multirow[t]{2}{*}{$\mathrm{ICOR}^{5)}$} \\
\hline & in USD & in \% of EU-15 & in USD & in \% of EU-15 & in EURO & in \% of EU-15 & \\
\hline Bulgaria & 1,200 & 6 & $4,304^{3)}$ & 21 & 0.63 & 6 & 5.50 \\
\hline Czech Republic & 5,047 & 23 & $9,545^{3)}$ & 47 & 1.94 & 18 & - \\
\hline Estonia & 3,300 & 15 & $5,736^{3)}$ & 28 & 1.57 & 14 & 7.68 \\
\hline Hungary & 4,400 & 20 & $8,085^{3)}$ & 40 & 1.69 & 15 & 4.11 \\
\hline Latvia & 2,288 & 11 & $5,346^{3)}$ & 26 & 1.09 & 10 & - \\
\hline Lithuania & 2,581 & 12 & 4,803 & 24 & 1.44 & 13 & 5.06 \\
\hline Poland & 3,500 & 16 & 6,740 & 33 & 1.90 & 17 & 5.07 \\
\hline Romania & 1,546 & 7 & 3,970 & 20 & 0.97 & 9 & - \\
\hline Slovak Republic & 3,624 & 17 & $8,566^{3)}$ & 42 & 1.52 & 14 & 7.96 \\
\hline Slovenia & 9,037 & 42 & $12,833^{3)}$ & 64 & 5.09 & 46 & 6.12 \\
\hline CEECs-10 & 3,186 & 15 & 6,435 & 32 & 1.61 & 15 & - \\
\hline Austria & 26,850 & 124 & 22,740 & 113 & 11.24 & 102 & 8.73 \\
\hline Belgium & 25,380 & 117 & 23,480 & 116 & 12.74 & 115 & 8.18 \\
\hline Denmark & 33,280 & 154 & 23,830 & 118 & 17.32 & 157 & 7.99 \\
\hline Finland & 24,110 & 112 & 20,270 & 100 & 11.87 & 107 & 4.15 \\
\hline France & 24,940 & 115 & 22,320 & 111 & 11.11 & 101 & 5.66 \\
\hline Germany & 25,850 & 120 & 20,810 & 103 & 16.71 & 151 & 10.00 \\
\hline Greece & 11,650 & 54 & 13,010 & 64 & 5.62 & 51 & 2.20 \\
\hline Ireland & 18,340 & 85 & 18,340 & 91 & 10.76 & 97 & 2.08 \\
\hline Italy & 20,250 & 94 & 20,200 & 100 & 8.26 & 75 & 12.08 \\
\hline Luxembourg & 43,570 & 202 & 37,420 & 185 & 14.72 & 133 & 8.18 \\
\hline Netherlands & 24,760 & 115 & 21,620 & 107 & 12.12 & 110 & 6.16 \\
\hline Portugal & 10,690 & 49 & 14,380 & 71 & 4.28 & 39 & 7.86 \\
\hline Spain & 14,080 & 65 & 16,060 & 80 & 7.91 & 72 & 6.96 \\
\hline Sweden & 25,620 & 119 & 19,480 & 97 & 16.00 & 145 & 5.51 \\
\hline United Kingdom & 21,400 & 99 & 20,640 & 102 & 11.80 & 107 & 8.31 \\
\hline EU-15 & 21,617 & 100 & 20,176 & 100 & 11.05 & 100 & - \\
\hline
\end{tabular}

1) GDP per capita at current exchange rates. - 2) PPP-GNP by the World Bank in 1998; some figures are extrapolated with the real growth rate per capita. - 3) Extrapolated from 1997 estimate by real GDP growth per capita. - 4) Gross wages and salaries excl. indirect labour costs. Note that the comparision is affected by national differences in methodology. CEE-10 countries: Gross monthly wages and salaries divided by working hours per month. EU-15: Extrapolation of 1995 figures by nominal wage index. - 5) Incremental Capital Output Ratio (ICOR): Low values of the ICOR are an indication for a high marginal productivity of the capital stock and vice versa. Note that the ICOR can only be calculated for positive growth rates of the GDP.

Sources: World Development Indicators, CD-Rom, Washington, D.C. 2000, IMF: International Financial Statistics, various editions, Washington, D.C. 2000; EUROSTAT, national statistical offices, authors' calculations. 


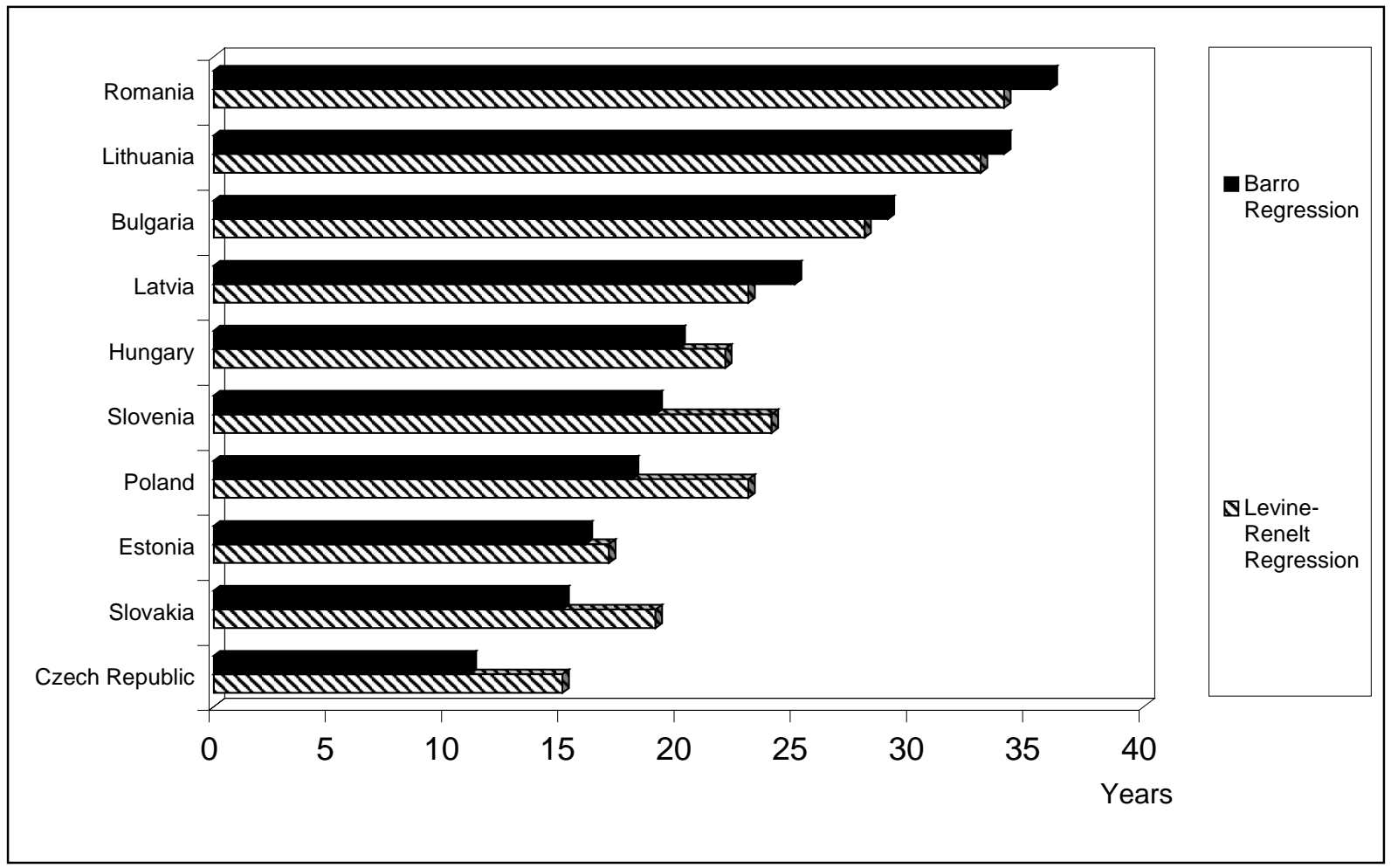

Sources: Authors' estimates and calculations. 


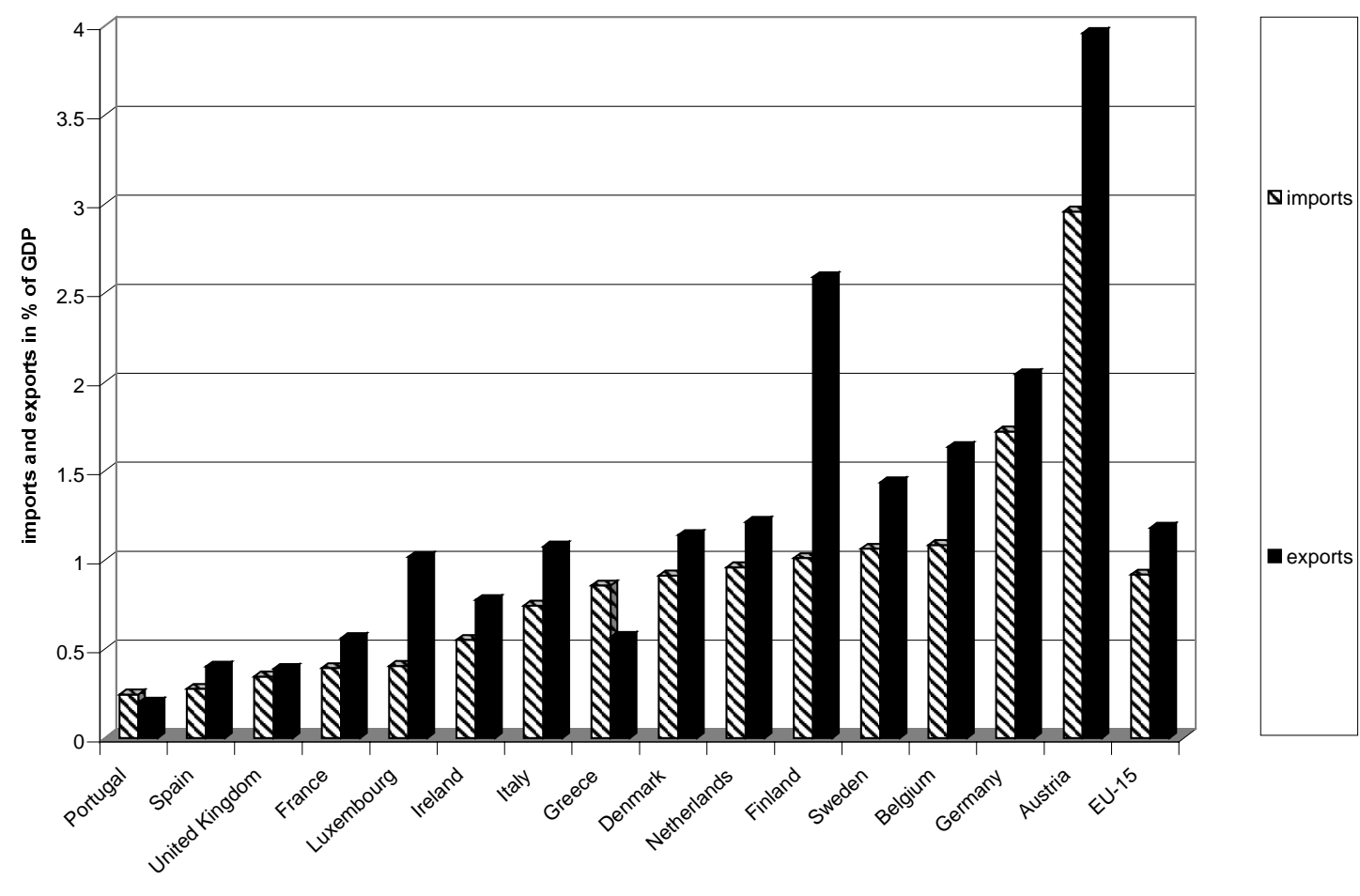

Sources: OECD, Direction of Trade Statistics, authors' calculations. 
Figure $3 \quad$ Nationals from the CEECs-10 in employment of the EU-15 members

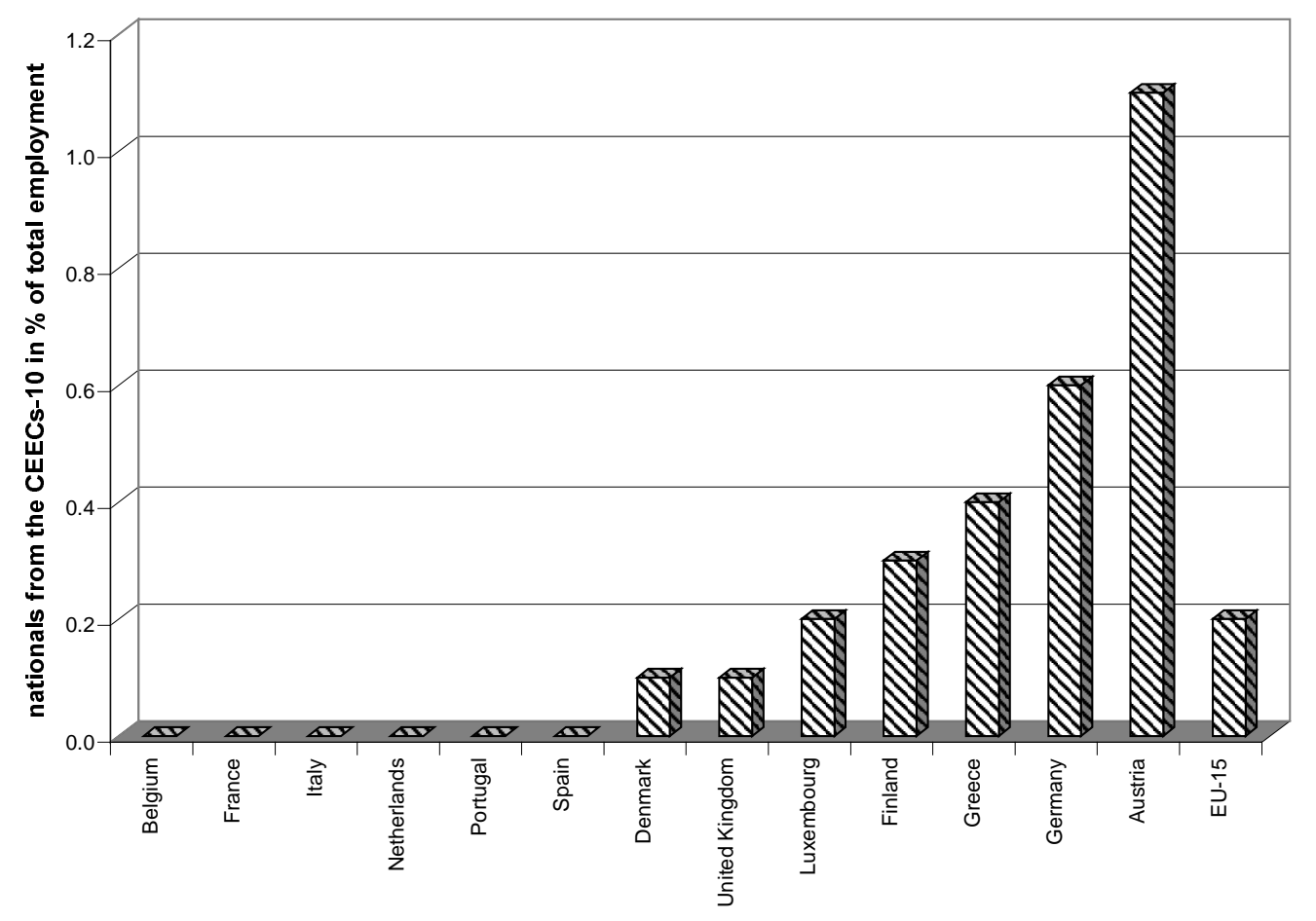

Sources: Eurostat Labour Force Survey, authors' calculations. 
Figure 4 Simulation: Foreign population in the EU-15 after introduction of free movement

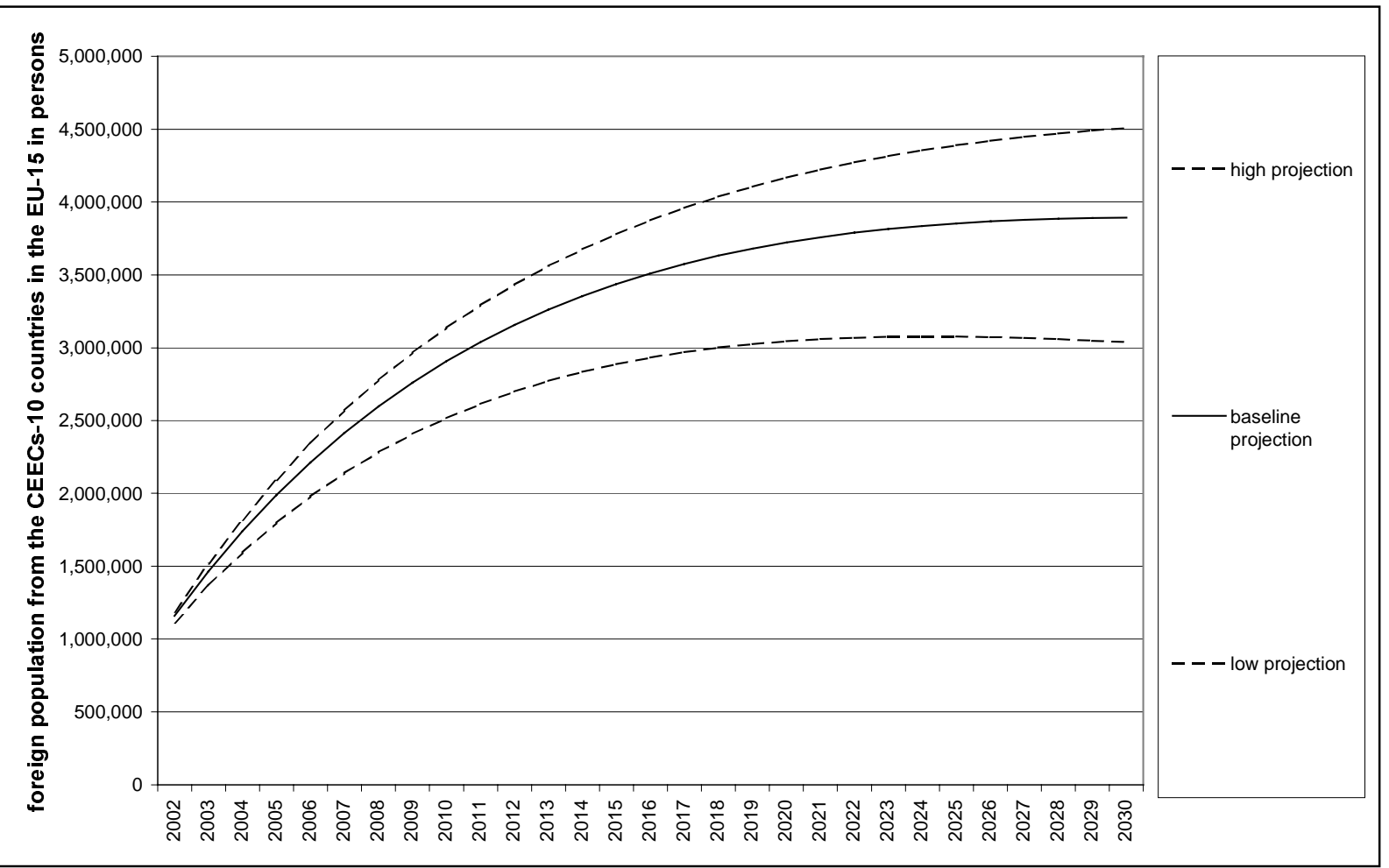

Sources: Authors' estimates and simulations. Note that in the high (low) projection a convergence rate of $3 \%(1 \%)$, an unemployment rate of $10 \%(5 \%)$ in the country of destination, and an unemployment rate of $15 \%(5 \%)$ in the country of origin is assumed. 


\section{IZA Discussion Papers}

\section{No Author(s)}
171 C. Dustmann
F. Windmeijer
172
D. Card

173

174

175

176

O. Hübler

W. Meyer

177 B. R. Chiswick

G. Repetto

178 R. Euwals

M. Ward

179 E. Wasmer

P. Weil

180 T. K. Bauer

I. N. Gang

181 E. Wasmer

Y. Zenou

182 M. Fertig

C. M. Schmidt

183 M. Fertig

C. M. Schmidt

184 M. Corak

B. Gustafsson

T. Österberg

185 H. Bonin

K. F. Zimmermann
Titel

Area

Date

Wages and the Demand for Health - A Life Cycle

5

Analysis

Reforming the Financial Incentives of the Welfare

System

Timing, Togetherness and Time Windfalls

5

$7 / 00$

Does Money Illusion Matter? An Experimental Approach

Self-Employment and Earnings among HighSkilled Immigrants in the United States

Industrial Relations and the Wage Differentials

between Skilled and Unskilled Blue-Collar

Workers within Establishments: An Empirical

Analysis with Data of Manufacturing Firms

Immigrant Adjustment in Israel: Literacy and

Fluency in Hebrew and Earnings

The Renumeration of British Academics

5

$7 / 00$

The Macroeconomics of Labor and Credit Market Imperfections

Sibling Rivalry in Educational Attainment:

The German Case

Space, Search and Efficiency

$8 / 00$

$8 / 00$

Discretionary Measures of Active Labor Market

Policy: The German Employment Promotion Reform in Perspective

Aggregate-Level Migration Studies as a Tool for 1 Forecasting Future Migration Streams

$8 / 00$

Intergenerational Influences on the Receipt of

3

$8 / 00$

Unemployment Insurance in Canada and Sweden

The Post-Unification German Labor Market

4

$8 / 00$ 
A. S. Kalwij

The Myth of Worksharing

A. Zaidi

Is Unemployment Really Scarring? Effects of

The Determination of Wages and the Gender 
220 W. A. Cornelius

E. A. Marcelli

221

C. Grund

222 W.P.M. Vijverberg

223 M. Rosholm

M. Svarer

J. Schwarze

L. Modesto

J. P. Thomas

P. A. Puhani

227

L. Locher
G. Brunello

S. Comi

C. Lucifora
R. Coimbra
T. Lloyd-Braga
L. Modesto

230

L. Modesto

231

G. Saint-Paul

E. Bardasi

M. Francesconi

C. Dustmann

C. M. Schmidt
The Changing Profile of Mexican Migrants to the

Wages as Risk Compensation in Germany

On the Identification of Relative Wage Rigidity Cross-Section Data and Empirical Evidence for Poland in Transition

Immigration from the Eastern Block and the former Soviet Union to Israel: Who is coming when?

The College Wage Gap in 10 European

\section{Fluctuations} and Earnings: An Empirical Study for Portugal 

1969-95 the 1990s

244 S. M. Fuess, Jr. M. Millea

Pay and Productivity in a Corporatist Economy: 
250 T. J. Hatton

The Optimal Level and Composition of Retirement Benefit Systems

Demographic and Economic Pressure on 